\title{
Celebrity Politics: The Politics of the Late Modernity?
}

\author{
David Marsh, Paul 't Hart and Karen Tindall \\ Australian National University
}

The academic literature on celebrity politics is rarely systematic; more often it is superficial and anecdotal. In addition, most of the literature focuses either upon classifying different types/categories of celebrity politicians and their roles in politics, or upon the question of whether the growth of celebrity politics undermines or enhances democracy. In this article we consider both of these issues more systematically and, in doing so, work towards a more coherent understanding of the mechanisms that influence modern governance and the operation of contemporary democracy.

As the spheres of the media, the entertainment industry and the political have begun to intersect more visibly, the resulting phenomenon of 'celebrity politics' potentially affects many facets of political life, for example campaigns and elections (Duvall, 2007), policy agendas (Brockington, 2009) and international affairs (Clarke, 2009; Cooper, 2008). Although systematic empirical research about its pervasiveness and impact is still lacking (yet see Duvall, 2007), there is a noticeable rise in media as well as academic interest in celebrity politics, reflecting the widespread belief that it is a growing phenomenon. Celebrity politics is probably present to different degrees in different political systems (Mukherjee, 2004; Street, 2004; West and Orman, 2003). Besides the avalanche of commentary on 'celebrity politics' in tabloids, gossip magazines, blogs, fan sites and occasionally business or news magazines, there are three strands of academic literature on celebrity politics: first, general books on celebrity (Braudy, 1986; Cowen, 2000; Gamson, 1994; Giles, 2000; Holmes and Redmond, 2006; Monaco, 1978; Rojek, 2001; Turner, 2004), most although not all of which have chapters or sections on politics; second, books and articles on the media and politics that to a greater or lesser extent touch on celebrity (Boorstin, 1961; Hartley, 1996; Meyer, 2002; Perloff, 1998; Street, 2005); and, finally, a limited number of books and articles specifically on celebrity politics (Cooper, 2008; Marshall, 1997; Mukherjee, 2004; Street, 2004; Van Zoonen, 2006; Weiskel, 2005; West and Orman, 2003).

Unfortunately, the academic literature on celebrity politics is rarely systematic; more often it is superficial and anecdotal. In addition, most of the literature focuses either upon classifying different types/categories of celebrity politician and their roles in politics or upon the question of whether the growth of celebrity politics undermines or enhances democracy. Our aim in this article is to consider both of these issues more systematically and in doing so work towards a more coherent understanding of the mechanisms that influence modern governance and the operation of contemporary democracy. 


\section{Celebrity Politics in Various Shapes and Sizes}

A number of authors have developed classifications of 'types' of relationship between celebrity and politics. There are two broad approaches: the first focuses on the origins of the celebrity and, thus, the resources the individual utilises in the political arena; the second is more concerned with the type of political action in which the celebrity is engaged.

Darrell West and John Orman (2003, pp. 3-4) exemplify the first approach, distinguishing between: political newsworthies, whom they see as the classic celebrities 'skilled at appearing on television and communicating with the general public'; legacies, mainly 'descendants of prominent political families'; famed non-politicos (elected officials), who are 'responsible for their own prominence' but move into elected office; famed nonpoliticos (lobbyists and spokespersons), who are also responsible for their own prominence but move into politics to promote a policy or cause without seeking office; and event celebrities, who are 'overnight sensations who arise on the local or national scene due to some tragedy or predicament'; they cite crime victims as an example.

Maxwell Boykoff and Michael Goodman's (2009) approach is similar. They identify six main categories of 'climate change celebrity politicos' (their examples in brackets): celebrity actors (Leonardo DiCaprio); celebrity politicians (Arnold Schwarzenegger); celebrity athletes/sports figures (David James, an England footballer); celebrity businesspeople (Richard Branson); celebrity musicians (Alanis Morrisette); and celebrity public intellectuals (George Monbiot, a UK writer and journalist).

The second approach focuses mainly on the extent and type of involvement that celebrities have in politics, regardless of the original source of their fame, although this approach also recognises that politicians can become celebrities and use celebrity. John Street's (2004) straightforward classification distinguishes between the celebrity politician, who is a traditional politician who engages 'with the world of popular culture in order to advance their pre-established political functions and goals', and the celebrity politician, who is an 'entertainer who pronounces on politics and claims the right to represent people and causes, but who does so without seeking or acquiring elected office' (Street, 2004, p. 437, p. 439). Jaideep Mukherjee's (2004, pp. 81-2) classification goes further, distinguishing among celebrity politicians between celebrity endorsers, who promote certain policy options, and celebrities who become politicians.

't Hart and Tindall (2009) attempt to capture this variety by distinguishing four categories of celebrity involvement in politics: celebrity advocates; celebrity endorsers; celebrity politicians; and the politician-turned-celebrity. In relation to each of these categories they develop a series of propositions that could inform future work on celebrity politics.

Most celebrities attach themselves to a charity or a cause, but celebrity advocates tend to be more active and more committed policy seekers. So Angelina Jolie, Bono and Bob Geldof have been very active over an extensive period of time, in contrast to the perception that some celebrities pay lip-service to a cause for publicity reasons. Celebrity 
endorsers champion particular political parties or candidates electorally. Perhaps the most conspicuous recent example is Oprah Winfrey, who actively campaigned for Barack Obama. Obviously, the status and credibility of the celebrity are likely to be important, as is the view that the general population has of them. So as Trevor Thrall et al. (2008), whose work we consider in more detail below, found, 'A-list' celebrities have more impact on media coverage of events about politics and politicians than lesser celebrities. At the same time, as the Forbes poll (Forbes.com/list/celebrities) found, while some 'A-list' celebrities, especially Winfrey, Tom Hanks and George Clooney, had a very positive impact on the images of candidates, others, including Tom Cruise and Madonna, had a negative impact.

In relation to both celebrity activists and endorsers, 't Hart and Tindall (2009) propose that the celebrities' charitable and political activities will be seen as more significant and successful: (a) the more merit-based the source of their initial fame; (b) the higher the social prestige of the cultural sphere in which the celebrity gained fame; (c) the more enduring the fame; and (d) the broader (geographical and numerical) and wider (across social strata and cultural groups) the scope of their fame.

Celebrity politicians are celebrities who go beyond one-issue politics and become office seekers. Ronald Reagan and Arnold Schwarzenegger are the most cited examples, though the phenomenon is more widespread in India or Indonesia than in the US or the UK (Hughes-Freeland, 2007; Mukherjee, 2004). To win office, celebrity politicians tend to capitalise on their position as popular public figures, combining it with self-conscious posturing as 'political outsiders', not 'tainted' with the awkward compromises, linguistic obfuscation and endemic opportunism that, they claim, professional politics imposes upon its practitioners. They are known, they are liked, and quite often they are rich - all attributes any ordinary newcomer to political campaigning craves. They are new, they are exciting, they are unpredictable - all attributes an incumbent politician they may run against has often long since lost.

However, celebrity politicians have to operate within an existing political system and culture which significantly affects their role and position. As such, 't Hart and Tindall (2009) offer three hypotheses. Firstly, the more that aspirants to political office in a particular political system are dependent for their election on existing political parties, the less widespread is the incidence of celebrities running for office. When a celebrity's individual brand is used to attract votes, conforming to the party line dilutes the perception that they can offer something new and different, and may be a less attractive option for a celebrity who is used to speaking their mind or acting individualistically. See, for example, criticism of former Midnight Oil frontman Peter Garrett, claiming that he had betrayed his former principles on environmental issues as an Australian Labour party MP (AAP, 2007). Secondly, the electorate may be more responsive to celebrities who seek to win office if overall levels of trust in the established political system and party politicians are low- and, disillusioned, they turn to more unconventional alternatives or political outsiders (though there are odd exceptions such as Finland, where there is both high trust yet high celebrity density in politics [Hautamaki and Kaarto, 2006]. Thirdly, as all celebrity politicians have to position their past life, which after all is the extra-political 
source of their celebrity, in the frame of their new political life, the larger the discrepancy between a celebrity politician's past and current lifestyle, espoused political values and policy preferences, the greater the likelihood that this celebrity will suffer credibility damage from selective media exposure of his or her past. Their challenge before, but even more so after, reaching elected office is to change the expectations and norms with which they are publicly judged. They now need to 'perform authority' (Hajer, 2009), not simply project their old public persona. By and large, Arnold Schwarzenegger managed to do so successfully, while the first celebrity governor, former wrestling star Jesse Ventura of Minnesota, did not.

Furthermore, 't Hart and Tindall (2009) also discuss the broader question of whether celebrity politicians are successful. They highlight the transience of most celebrity politicians and suggest that, in established democracies, the average tenure of celebrity politicians is shorter than that of professional ones, in part because the characteristics that attract voters often alienate legislators. Nevertheless, they cite Reagan and Schwarzenegger as successful politicians and propose that celebrity politicians are more likely to be successful in presidential, rather than parliamentary, systems.

Politician celebrities reverse the direction of the flow between politics and celebrity. Here, the focus is upon established politicians who enter the sphere of celebrity. Such politician celebrities are coming to terms with the media age and consumer culture, attempting to personalise or 'brand' their leadership, and are constantly adapting their political communication strategy to communicate through evolving media, such as radio, television and the internet. As 't Hart and Tindall (2009, p. 259) note: 'Democratic politics, like marketing has always been about persuasion; but these days the techniques used in persuading publics of the merits of certain ideas, parties and people have become almost indistinguishable from those used in "branding" firms, products and indeed "stars" .

Of course, this raises issues about the relationship between celebrity politics and governance, which we return to below. However, the point here is that contemporary politicians are inexorably drawn into the media realm and - leaders at least - increasingly adopt the role of celebrity.

\section{Developing the Typology}

The crucial distinction embedded in the 't Hart and Tindall typology is that between celebrities who engage in politics (as commentators, policy advocates, endorsing a candidate or running for elected office) and politicians who use 'celebrity' by celebritising their personal image. Debates about whether celebrity politics enhances or constrains democracy focus either on the way in which celebrities interact with politicians and politics or on the way in which politicians use celebrity. So the majority of the literature focuses upon an assessment of the role of pre-existing celebrities in politics and the extent to which they enhance democracy, either by engaging with citizens who are normally apolitical or, helped by the media, acting as a check on executive power; or to which they constrain democracy because they have undue power or influence. In contrast, the more limited 
material on celebrity and governance, especially the work of Henrik Bang discussed below, is more concerned with how politicians and other policy makers use celebrity, either by attempting to become celebrities themselves or by using celebrities to help legitimise their policies. As such, there is an important fifth category omitted from the 't Hart and Tindall classification. This refers to instances where politicians use (other) celebrities to achieve their own purposes. While 't Hart and Tindall (2009) discuss the celebrity endorser, this fifth category draws attention to the other individual in the endorser/candidate relationship. Consequently, this category features in the adaptation of the heuristic typology outlined in Table 1.

\section{Celebrity Politics: Governance and Democracy}

The developing links between celebrity and politics are probably best understood as part of a longer-term process in which political systems and political actors adapt to the technological, social and political change associated with what is most often termed late modernity. As such, celebrity politics raises immediate questions about the nature of modern governance and the operation of contemporary democracy. These two questions are often conflated in the literature, but they are distinct, even if related. Here, we consider the two issues separately.

\section{Politics and Governance}

Sociologists argue that we have moved into a period of late modernity (Beck, 1992; Giddens, 1991; Lash, 1990) or reflexive modernity (Beck et al., 1984), characterised both by growing complexity, reflected in changes in economic, socio-cultural and political processes, and by increased reflexivity.

This debate has permeated political science, particularly in the literature on governance (Bell and Hindmoor, 2009; Pierre and Peters, 2000). Here, the work of Henrik Bang (2003; 2004; 2005; 2007; 2008; Bang and Sørensen, 2001) is particularly interesting, given that an important part of his focus is upon the role that celebrity politics plays in relation to the changing nature of governance resulting from the problems of governing in late modernity. Bang sees the politics of late modernity as characterised by: the replacement of hierarchy by networks as the dominant mode of governance; the hollowing out of the state; a move from politics policy to policy politics; the increased fluidity of identity, including political identities, coupled with a greater reflexivity; changing forms of political participation; the increased importance of the discursive arena for network governance and the associated rise of the role of the media and celebrity politics; and the changing nature and role of parties. These are crucial claims which, to the extent that they are true, change the nature of politics and the political and, perhaps most crucially, of contemporary democracy.

Bang's argument is interesting in that unlike most of the literature, it situates the rise of celebrity politics in a broader context. In fact, there are two thrusts to Bang's work and both emphasise the importance of celebrity politics. Initially he focused upon the changing nature of politics and citizens, and in particular the development of new forms 

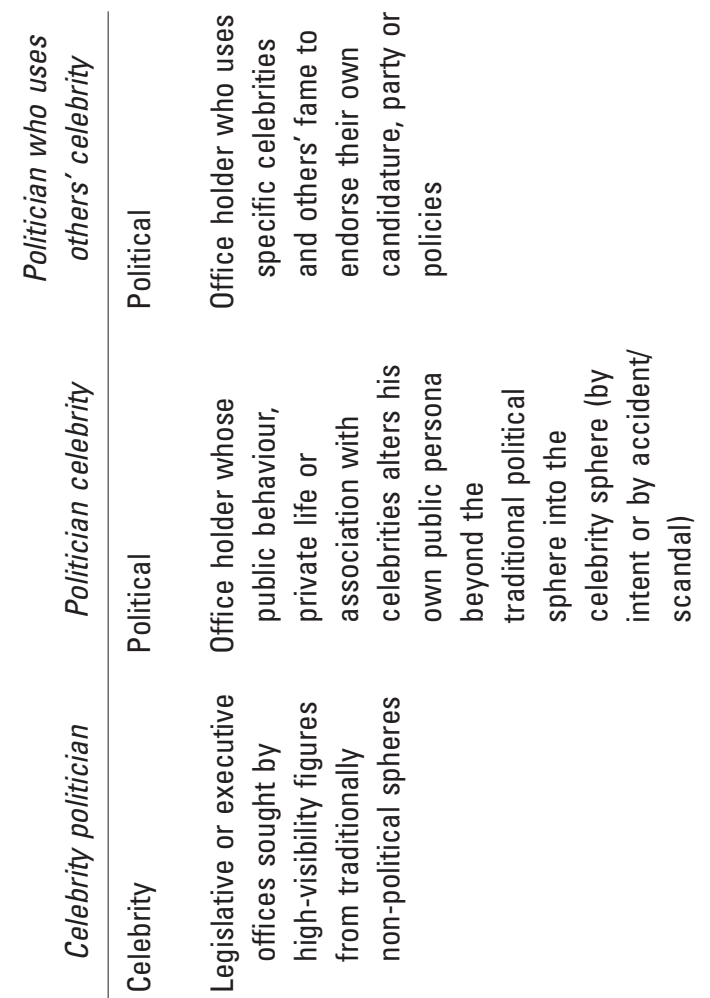

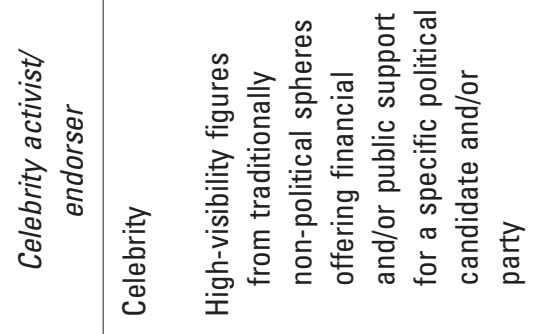

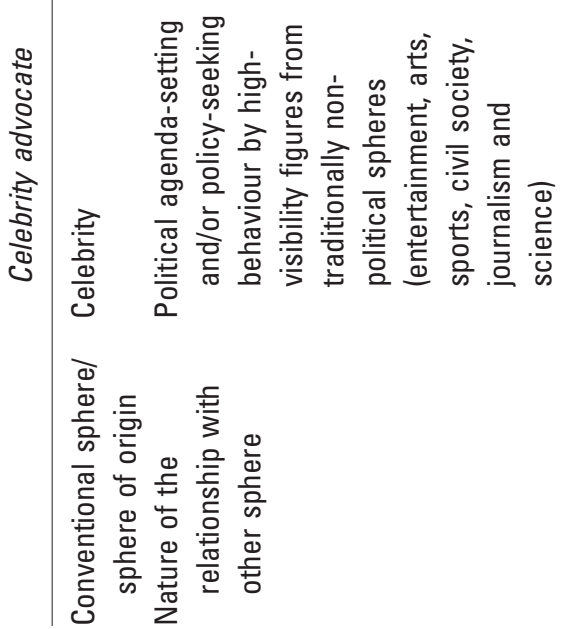


of political participation, and how this has changed the ways in which politicians need to engage with citizens. More recently he has focused upon the move from what he terms politics policy to policy politics.

'Everyday Makers' and Celebrity Politics. To Bang (2004), citizens are increasingly reflexive and a growing number act as Everyday Makers; they are not apathetic, but are unlikely to engage directly with the state. In addition, they have no interest in producing a new form of interest representation and have minimal interest in party politics. Similarly, they are not driven by a sense of duty, or by an ideology; nor are they interested in gaining influence, but rather they wish to feel involved and develop themselves.

In Bang's view, the problem for politicians here is that Everyday Makers' political activity is not generalisable, as it is not based on ideology or membership of any group; nor can it be relied upon, given that it is ad hoc and done for fun. Consequently, politicians need to engage on a continuing basis with citizens persuading them to participate. To do so, they use the media and celebrity.

Bang's work is theoretically developed, but relatively empirically light. However, he has recently focused on the Obama US presidential campaign as an example of how a contemporary politician can engage with Everyday Makers. Here, Bang enthuses (2009, p. 2):

At its high point, my.barackobama.com (MyBO) had 2 million active users, more than 100,000 profiles and 35,000 affinity groups, and was the coordination point for 200,000 events. In addition, 70,000 people raised $\$ 30$ million using $\mathrm{MyBO}$, while in the last four days of the campaign, users made 3 million telephone calls as part of the get-out-the-vote effort.

Bang's (2009, p. 2) argument is that:

Obama articulated an image of himself as an inspiring political authority who does not expect a 'blind' or rationally motivated form of obedience (as do mainstream political leaders). He spoke about authority as a reciprocal and communicative, two-way power relationship that combines goals, tactics and ethos in order to get people with different, and sometimes even incompatible, identities and projects freely to accept that cooperation across all conventional boundaries may be the only way to resolve the common challenges and problems of the United States and the world in general.

According to Bang, this relationship was facilitated and endorsed by Obama's (and his family's) increasing celebrity status and the interactions between him and his Everyday Maker supporters through the use of new technology.

This is an interesting argument, but again its empirical basis is limited. Certainly there was broad engagement with the Obama campaign, it used new technology in innovative ways and Obama's charisma and increasing celebrity probably played a crucial role in his success. However, we are not told how many of those involved in helping Obama can be regarded as Everyday Makers (certainly some of the more conspicuous ones were typical 
celebrity endorsers of the Oprah Winfrey/Bruce Springsteen variety). Nor do we learn how important Obama's celebrity or his more participatory style were in getting people involved in supporting him. Thirdly, Bang is silent on the counterfactual question that many US election watchers addressed: did Obama really do much better than Hillary Clinton would have? The answer to this question in purely electoral terms is 'probably no', but a Bang-style analysis of the question might have usefully pointed out that an exclusively electoral balance sheet is far too narrow a method of assessing the Obama campaign's political impact. Finally, what is conspicuously absent from Bang's treatment of Obama and his appeal is any consideration of the extent to which it was simply his policy positions that might have attracted voters, particularly when compared to the awkward struggle his opponent McCain was waging to simultaneously repudiate and salvage the then deeply unpopular Bush administration policy platform.

'Policy Politics' and Celebrity Politics. Bang also contends (2007) that contemporary governance networks operate in three arenas: parliamentary; corporatist; and discursive. He argues that the first two arenas are becoming less important, while the discursive arena is becoming more important, because it is crucial for attempting to resolve the tension between the complexities of late modernity and the imperative involved in the need to produce effective public policy. The idea here is that contemporary states are under more pressure dealing with increased complexity and, for that reason, incorporate more elites into the policy-making process.

In Bang's view, in contemporary network society identities and policy emerge through the networking process as a result of discursive engagement among the network elite. At the same time, this elite engages in a broader discursive arena, utilising its media expertise, in order to convince citizens that they have the answers to the problems they face. As such, Bang $(2007$, p. 8) identifies a shift from an input-output model of politics, in which inputs from citizens, via parties and interest groups, were negotiated and aggregated into policy outputs by government (in his terms a period of politics policy), to a recursive one, in which the network elite, operating through the political system, acts 'in its own terms and on its own values, thereby shaping and constructing societal interests and identities' (in his terms a period of policy politics).

In Bang's view, then, increased complexity and reflexivity and the accompanying move from politics policy to policy politics have also led to a significant change in the nature and role of political parties. This is an issue which John Corner and Dick Pels (2003) also take up, but they merely argue that 'parties have been blurring boundaries and levelling the hierarchy between high political representation and low popular entertainment' (p. 5). This is a relevant, if limited, point. Bang takes this argument in a more interesting direction. He acknowledges the validity of many of Mark Blyth and Richard Katz's (2005) conclusions about the rise of the cartel party. However, he sees this rise more directly as a response to the shift towards policy politics and argues that, more recently, cartel parties have been superseded in many countries by what he terms expert-celebrity parties.

To Bang, the cartel party was an initial response to problems of late modernity. Governments need to involve elites in governing networks to manage increasing complexity, 
hence the move to network governance. At the same time, they need legitimacy, which is only available through elections and can only be achieved if parties can convince citizens (Bang terms them lay people) that they are offering, and can deliver, what citizens want. As such, cartel parties aim to control the state and use that control to produce necessary policies and convince the electorate that these policies have met/will meet their needs. Cartel parties do not encourage active, involved members; rather, they need individual members to proselytise and legitimise the party's policies and power.

In contrast, Bang argues that from the 1990s we have seen the development of expertcelebrity parties. As complexity has increased, and as individuals have become more reflexive (producing different types of political participant, including Everyday Makers), so the limitations of the cartel party have been exposed. Increased complexity has made governance more difficult, so while in the 1970s networks and hierarchies perhaps coexisted as modes of governance, now network governance is clearly the dominant mode. This means that parties have become part of what Bang terms glocalised policy politics networks, involved in a series of exchange relations aimed at achieving good governance. Such good governance is essential if the governing party is to be re-elected, but so is the presentation of the party, the government and the policy. Consequently, parties use the media tools of celebrity (blogs, appearances on popular TV shows, personalised websites, etc.) to communicate with the electorate. In this type of party, voters and members are not sources of policy ideas. Rather, members are valued largely in terms of how they can be used to communicate the message of good governance, and the electorate is there to be convinced.

A problem with Bang's work is that his argument is not easy to address empirically. It is certainly true that politicians and parties increasingly use the media tools of celebrity and that political marketing has become a very important feature of contemporary politics (Needham, 2005; Pringle, 2004). Yet Bang's key assertions are often contestable. First, of course, there is the issue of whether we are witnessing the rise of network governance and the decline of hierarchy. While this is almost the starting point of Bang's analysis, it is contested by many authors who see hierarchy as remaining the dominant mode of governance, certainly in Westminster systems (Bell and Hindmoor, 2009; Marsh, 2008; Marsh et al., 2003). Second, Bang argues that network governance uses celebrity and the media to garner support for policies among lay people. However, this appears to deny any independent role for the media (compare Meyer, 2002). It also seems to reject the argument that parties, while less ideological, as Bang would argue, are more influenced by citizens' views or, to put it another way, the argument that we have moved to government by focus groups. Third, Bang pays no attention to the view that even the network society remains characterised by structured inequalities producing policies that reflect the interests of those in the network and are then marketed to citizens using the media and celebrity.

\section{Celebrity Politics and Democracy}

Notwithstanding these loose ends, Bang's analysis does raise important issues about the relationship between celebrity, politics and democracy. To the extent that celebrity is 
used to legitimise policy decisions taken in expert networks, this might well undermine representative and parliamentary democracy. Bang is not sanguine about the future of democracy, but for him hope lies with the Everyday Makers and their refusal to accept at face value what politicians or experts advocate, or, to put it another way, the future of a vibrant democracy depends on the reflexivity of Everyday Makers. Overall, there is no doubt that the putative prominence of celebrity politics has implications for the nature and future of democracy and this is an issue that a number of authors have discussed.

The majority of the literature on the relationship between celebrity and democracy tends to see the former as compromising the latter, although there are some authors who see the effect of celebrity as beneficial. These views hinge partly upon the vision of democracy that is adopted. While largely problematic for the proponents of conventional representative democracy (see below), celebrity politics can powerfully enhance what John Keane (2009) calls 'monitory democracy', in which the key of democratic process is no longer with representation and interest aggregation on the input side of politics, but rather with the organisation of 'voice' and accountability on the output side. Interestingly, the two positions tend to share the view that celebrities have influence; the debate is largely over whether the effect of that influence is positive or negative for the functioning of contemporary democracy. Here we begin by reviewing those arguments that suggest that celebrity restricts democracy, before considering those that see it as enhancing democracy and, finally, considering the limited empirical literature on the influence of celebrities and celebrity on politics.

Celebrity as a Constraint on Democracy. In essence, celebrity activists and advocates are leaders whose followers may be far more interested in the individual and his or her creative product than in also supporting his or her chosen cause. This raises thorny issues of representation and democracy. Who or what can Jolie or Bono legitimately claim to represent? Their fame may command a salary of millions and the front page of any number of magazines, and their political causes encompass a wide range of society's ills, but it would be a large stretch to argue that their leadership is embedded in some form of cosmopolitan democracy (Held, 1995; Saward, 2006).

If the issue of representation is the most important one, the question of the extent to which celebrity trivialises politics has received the most attention. In this vein, David Meyer and Joshua Gamson (1995) emphasise that celebrities shift the nature of media coverage towards a focus on a more personalised and dramatic style. Of course this argument is taken further and it is variously suggested that the increasing role of celebrity in politics leads to a lowering of the quality of politicians, who are valued for their style or looks rather than their abilities, and to the dumbing down of political debate, when politics has increasingly become about (masculine) personalities, image and spin, and less about policies (see Van Zoonen, 2006). From this perspective, in-depth analysis and careful deliberation are at risk of being replaced by star power, marketing, rock concerts, stylists and cleverly made, but ultimately shallow, docu-pics, facebook profiles, twitters, blogs and 'pseudo events' (Drezner, 2007; Weiskel, 2005). 
In addition, the strong amplification that celebrity voices receive in the public discourse may crowd out the perspectives provided by other, less famous interlocutors. Top celebrity activist Bono, for example, is advised on economic policy by Jeffrey Sachs - the man whose ardent belief in 'shock therapy' has brought various 'new democracies' economic chaos and political turmoil, and who has since revised his theories (see Klein, 2007). Policies on debt relief masterminded by Sachs and amplified by Bono are the ones that get beamed to the public through mega-spectacles such as the Live 8 concerts. Other theories and policy formulas hardly compete on a level playing field. Perhaps even more importantly, the focus on the policies that celebrities endorse can devalue the social problems and unpopular, controversial or unglamorous causes to which celebrities pay little attention.

Some have gone much further in their critique, emphasising the broader rise of entertainment culture and its relationship to the dominance of market forces. So Tyler Cowen argues $(2000$, p. 171) that 'Modern commentators often criticise politics and citizenries for their low standards and their ignorance. In reality they are observing the consequences of a culture that is based on scrutiny of the famous and driven by the quest for profits'. However, this argument is developed most forcefully in David Marshall's Marxist critique of the effect of celebrity on politics and democracy, focusing upon how power is articulated through celebrity. In essence, he suggests (Marshall, 1997, p. xiii) that celebrity involves 'the migration of communicative strategies from the entertainment industries and public relations into the organisation of the spectacle of politics'. More generally, he contends: 'Fundamentally, celebrities represent the disintegration of the distinction between the private and the public' (Marshall, 1997, p. 247). As Philip Drake and Michael Higgins emphasise (2006, p. 87), for Marshall, celebrities and capitalism are both seen as rooted in and promoting individualism: 'both celebrities and politicians promote similar myths of individualism, and construct a public form of subjectivity that expresses freedom and aspiration in a capitalist democratic society'. From this perspective, political celebrity is a key means in late modernity by which the economic and politically powerful retain control of that power.

Celebrity as an Enhancement of Democracy. Some authors also suggest that a celebrity regime is not necessarily detrimental to modern society and can be beneficial to our political system. One of the critiques West and Orman (2003, p. 111) put forward regarding the overlap of celebrity and politics is that:

At least in the abstract, it offers the potential to reinvigorate American politics by introducing new blood and new ideas. Unlike conventional politicians, celebrities do not have to serve lengthy apprenticeships before they can run for major offices. They typically are less beholden to vested political interests because of their own wealth or ability to raise money from friends and family members. In a political world where entangling alliances are the rule, these kind of individuals are as close to autonomous free agents as one can find in the American political process.

A crucial element of the argument here is the idea that celebrity endorsement and activism can, and do, frequently serve to harness and even reinvigorate democratic politics. Some of 
it is actively aimed at stimulating public involvement and demanding greater transparency from policy makers. Celebrity-led debate can also educate segments of society on public issues about which they would otherwise remain ignorant (George Soros' extensive programmes in Central and Eastern Europe come to mind), and thus enhance their 'monitory' vigilance vis-à-vis the truth claims and executive power wielded by governments and dominant coalitions. In addition, while celebrities and the media may simplify complex political debate in a way that concerns the 'chattering classes', such simplification may make the issues more accessible to the less politically knowledgeable and interested.

Celebrity politics may thus provide an unorthodox, but potentially effective, way of breaking the hold of established elites on political agendas and public discourse about policy. Celebrities have a unique capacity to reach out to and mobilise otherwise apathetic publics, and sometimes manage to give powerful voices to the disenfranchised in society and on the world stage. Where legislatures and other institutional watchdogs may be fully coopted by executive dominance, celebrity-led initiatives can help 'keep the bastards honest'.

Cowen's argument is one of the most interesting, yet problematic, here. He begins (Cowen, 2000, 169) by suggesting that the growth of political celebrity has had both negative and positive outcomes. However, he concludes that it has had a largely positive effect, despite the fact that it has, in his view, resulted in the election of poorer quality politicians: 'Although it is harder to install bold and innovative visionaries in political positions than it used to be, the danger of political abuse and very bad outcomes is small as well' (Cowen, 2000, p. 169).

In essence, he is developing a neo-liberal argument in favour of governments with less capacity to intervene. As such, he argues, contra Hobbes, that 'Fame and media scrutiny achieve the Hobbesian result of risk suppression, but without creating political instability. The burdens of fame provide a new means of limiting political leaders' (Cowen, 2000, p. 170).

He also takes issue with the communitarians' view that the quality of public discourse can 'secure political order and justice' (Cowen, 2000, p. 170), which he sees as utopian, because the 'fame intensivity' of what he terms 'a free and commercial society' undercuts the quality of public discourse. Or as he puts it, 'the very nature of commercial fame corrupts that discourse and creates a world of illusion and make-believe' (Cowen, 2000, p. 171).

So for Cowen the fact that celebrity politics produces less able leaders, who are, to an extent, creatures of the media, is a positive thing for democracy because these leaders are less decisive, less interventionist and more constrained by the powerful (if unconventional) accountability mechanism of celebrity-focused performance expectations enforced by media monitoring. This is an imaginative but obviously contentious assertion.

\section{Does Celebrity Matter in Politics? Empirical Contributions to the Debate}

It is interesting that almost all those who write about celebrities and politics take it as axiomatic that, in contemporary society, celebrities exercise political power/influence. 
However, there has been little attempt in that literature to demonstrate empirically or assess systematically that influence. Most often, individual celebrities are invoked as examples of the various categories of celebrity politics discussed above, but there is no systematic attempt to study their influence, or the ways in which their celebrity affects that influence. There are only limited exceptions to that pattern. Here we look at three different types of analysis of political celebrities: the first is a study of the role of an individual celebrity, Oprah Winfrey, in the Obama campaign (Garthwaite and Moore, 2008); the second is a broader study of the role of celebrities in US politics (Thrall et al., 2008); and the third is the case of the 2005 Live 8 concerts, and the Make Poverty History and ONE campaigns, where we draw on a broader variety of material.

\section{The Most Powerful Celebrity Endorser? The Political Role of Oprah Winfrey}

Craig Garthwaite and Timothy Moore (2008) assert: 'While there have been no empirical estimates of the effect of celebrity endorsements on political outcomes, it is clear that celebrities have the ability to influence the behaviour of their fans in other arenas'. However, unlike many others who share this view, they attempt to measure the extent of that influence, focusing on Oprah Winfrey who turned her attention to politics when she endorsed Barack Obama in the 2008 presidential election.

Garthwaite and Moore (2008) point out that, by some measures, Oprah is one of the world's most well-known faces; her show is broadcast in nearly 150 countries and she held the 2008 top place on the Forbes 'hundred most powerful celebrities' list. She also has a significant influence on consumer decisions, particularly via the Oprah Book Club (which has a major effect on book sales; see Garthwaite and Moore, 2008, table 2) and her very popular monthly magazine, the Oprah Magazine, which has a circulation of over 2 million. It has also been suggested that she can have significant influence on the voting decisions of her fans. In this vein, a Forbes Magazine poll in 2007 found that 14 per cent of likely voters, including 11 per cent among those over 45, but 26 per cent among those aged 18 to 24, said they would be positively influenced by Oprah Winfrey's endorsement of a candidate. However, in 2008, while the Pew Research Centre found that 14 per cent of their sample said Oprah's endorsement would make it more likely that they would support Obama, a similar percentage said it would make it less likely, while 69 per cent said that it would have no influence on their vote.

Garthwaite and Moore (2008) utilise a sophisticated research design to examine the influence of Oprah's endorsement of Obama on his performance in the Democratic primaries. They use per capita circulation of the Oprah Magazine as a proxy measure for the number of fans she has in particular counties. Their model predicts 'that in areas with a greater number of fans the endorsee (Obama) should enjoy a greater degree of political success and there should be higher levels of voter participation' (Garthwaite and Moore, 2008, p. 24).

They conclude (Garthwaite and Moore, 2008, p. 3):

Oprah Winfrey's endorsement of Barack Obama prior to the 2008 Democratic Presidential Primary generated a statistically and qualitatively significant increase 
in the number of votes received as well as in the total number of votes cast. For example, after controlling for a wide variety of socio-economic factors such as race, gender, education and income, a 10 percent change in the county-level circulation of Oprah Magazine is associated with an increased vote share for Obama of 0.2 percentage points ... In terms of voter participation, a 10 percent change in circulation is associated with a 0.06 percentage point increase in turnout. Similar effects from the endorsement were found in areas with differentially high sales of books included in Oprah's Book Club. In total, we estimate that the endorsement was responsible for 1,015,559 votes for Obama.

\section{The Influence of Celebrity Advocacy}

Thrall et al. (2008) undertake a broader analysis of the effect of celebrity. First, they constructed two celebrity samples:

(1) a random sample of 147 celebrities drawn from a website, Celepedia, which 'lists thousands of current celebrities great and small' (Thrall et al., 2008, p. 366);

(2) the 2006 Forbes 100 ranking of the most powerful celebrities in the US.

Subsequently, they collected evidence of advocacy by these celebrities using four methods:

(1) they consulted the celebrities' own websites;

(2) they undertook a websearch, using each celebrity's name and key words like 'advocacy', 'politics' and 'charity';

(3) they searched the Nexis US database, using the same search terms; and

(4) they created a 'star power' rating, based on the number of hits for each celebrity's name on Google and the number of news stories about them in Nexis US.

They found that:

(1) 63 per cent of the celebrities in a random sample engaged in advocacy - on average they were active on 1.8 issues.

(2) In contrast, celebrities in the Forbes top 100 were much more active, with 90 per cent engaged in advocacy on an average of 4.16 issues.

(3) Perhaps unsurprisingly, 'star power' and advocacy were intimately related, with more advocacy by the biggest 'stars'.

So celebrities were advocates, and bigger celebrities were more active advocates. But was this advocacy effective? Thrall et al. (2008, p. 369) argue: 'conventional wisdom has oversold the power of the average celebrity to move the news machine and thereby shape policy agendas'. This argument is substantiated by an empirical analysis of the role of 165 celebrities engaged in environmental advocacy who were connected with 53 environmental groups. They found that there were factors much more important than celebrity star power driving news coverage of the environmental groups. Large, well-funded and established groups do not need celebrities to get access to the news-making process, whereas smaller groups gain little coverage with or without celebrity help. They also traced coverage of global warming in the New York Times between 1981 and 2007 and 
found that rises in coverage of celebrity advocacy did not appear to precede increased media coverage of global warming (Thrall et al., 2008, p. 372).

Overall, Thrall et al. (2008, p. 381) argue that there has been more advocacy by celebrities, but that they have much less impact on news than one might expect: 'mainstream news media ... have been less vulnerable to celebrity influence than many expect'. As such, they contend that 'star-powered advocacy is more important for mobilisation and building social movement infrastructure than it is for mass agenda setting and persuasion' (Thrall et al., 2008, p. 381). This is a much-needed, sobering, balanced, precise voice in an otherwise largely sweeping, fact-free debate.

\section{The Live 8 Concerts and the Make Poverty History/ONE Campaigns: A Case Study}

The Make Poverty History (MPH) campaign, which was branded differently as ONE in the US, provides a useful case to address questions about the impact of celebrity politics. The simultaneous Live 8 Concerts on 2 July 2005 were a particular feature of the campaign, timed to occur days before the G8 summit at Gleneagles, although, as Nick Sireau and Aeron Davis (2007) show, there was considerable criticism from radicals within $\mathrm{MPH}$ about the way in which Live 8 , and the celebrities associated with it, in the view of the radicals changed the focus of the campaign by allying with the government, and concentrating on Africa rather than poverty more generally.

Even so, as one of its observers emphasises, 'the campaign was created as show business ... [it] was made for the media' (Nash, 2008, p. 173). Kate Nash's own study of it focuses on what she terms the cultural politics aspects of MPH in the UK, while Sireau and Davis (2007) view MPH as a social movement. In the US, Sharon Fain (2008) analyses the discourses utilised in three ONE TV ads and an interview with Brad Pitt, which dealt, among other things, with his relationship to ONE. In addition, there was a DATA (Debt, AIDS, Trade, Africa) report which reviewed what had been achieved by Live 8 and associated activity (Kaufman, 2006).

The DATA report assesses the extent to which the G8 had delivered on the commitments made at the G8 summit, commitments that many at the time suggested were, in part, a result of the ONE/Make Poverty History campaign and Live 8. The report emphasises that: nineteen countries had cancelled 100 per cent of the debt they were owed; the US had increased development assistance to Africa by $\$ 400$ million, but this needed to be raised to $\$ 720$ million to meet their commitment; there had been no progress on a trade deal; and the G8 had spent an extra $\$ 1.6$ billion on Africa in 2005 , but needed to raise it to $\$ 3.9$ billion to meet their commitments. So despite the commitments made by politicians in front of the news cameras, there is limited evidence of a substantial change in the G8 commitment to Africa and even less that the extra aid resulted from celebrity pressure.

Fain's analysis of the ONE TV ads and the interview with Brad Pitt are interesting. She emphasises the limitations of the narratives about poverty and other causes in the ads. 
First, she emphasises that celebrities are narrated as Northern saviours attempting to solve the problems of Africa. Second, and most crucially, the ads are permeated with the discourse of consumerism and individualism: 'The consumerism and individualism displayed in ONE presents a misleading notion that all power and agency rests with the individual, neglecting to recognise how structures and systems can enable and disable agency' (Fain, 2008, p. 9).

George Monbiot (2005) develops this second point in his analysis of the MPH march in 2005. He contends that 'the new consensus denies that there is a conflict between ending poverty and business as usual' and is critical of the MPH campaign, arguing:

Without a critique of power, our campaign, so marvellously and so disastrously inclusive will merely enhance that effort. Debt, unfair terms of trade and poverty are not causes of Africa's problems, but symptoms. The cause is power: the ability of the G8 nations and their corporations to run other people's lives.

He concludes: 'At the Make Poverty History march, the speakers insisted that we are dragging the G8 leaders kicking and screaming towards our demands. It seems to me that the G8 leaders are dragging us dancing and cheering towards theirs'. Of course, Monbiot (2005), like Fain (2008), is suggesting that, in so far as these campaigns and their celebrity leaders had an influence on policy, it was in a way that perpetuated, rather than reduced, inequalities. To both these authors, the key point is that celebrity occurs within a political and economic system characterised by structured inequality, where some interests are favoured at the expense of others.

\section{Concluding Remarks}

We cannot resolve the empirical or the normative issues raised in this review article. Rather, our aim has been to set out the key issues in the literature on celebrity politics in a more systematic way. The literature has tended to focus either on attempting to develop a classification of different types of celebrity politics or on arguments about how celebrity politics relates to democracy. We addressed both these issues, while also raising the question of the relationship between celebrity and contemporary governance. Our intention has been to introduce readers to the issues involved and provide a foundation for further research in this area.

Although we at present lack robust numbers, it is safe to say that in many countries around the world celebrity politics has become more than a fringe phenomenon. Nor is it likely to be an ephemeral one. It is inextricably tied to the late-modern constitution of the public sphere and it is therefore here to stay. We consequently need a great deal more systematic empirical work to grasp its nature, dynamics and impact. Only then will we perhaps be able to arrive at a more balanced assessment of its place in contemporary politics, democracy and governance.

(Accepted: 14 January 2010) 


\section{About the Authors}

David Marsh is Director of the Research School of Social Sciences at the Australian National University. Previously he was Professor of Politics at the University of Birmingham in the UK. His main research interests are in political sociology and public policy. He is the author or editor of eighteen books and almost a hundred articles or book chapters. He is currently engaged in research on policy transfer between the UK and Australia and within Australia and is also undertaking a comparative study of governance in the UK and Australia.

David Marsh, Director, Research School of Social Sciences, Australian National University, Coombs Building, Canberra ACT 0200, Australia; email: David.Marsh@anu.edu.au

Paul ' $t$ Hart is Professor of Political Science at the Australian National University, Professor of Public Administration at Utrecht University and a core faculty member of the Australian New Zealand School of Government. Recent publications include Framing the Global Meltdown (ANU E-Press, 2009), Dispersed Democratic Leadership (Oxford University Press, 2009), The Real World of EU Accountability: What Deficit? (Oxford University Press, 2010) and How Power Changes Hands: Transition and Succession in Government (Palgrave, 2010).

Paul 't Hart, Research School of Social Sciences, Australian National University, Coombs Building, Canberra ACT 0200,Australia; email: hart@coombs.anu.edu.au

Karen Tindall is a $\mathrm{PhD}$ candidate in Political Science at the Australian National University. Her research is on crisis management. Her publications include Framing the Global Meltdown (ANU E-Press, 2009), 'Crisis Leadership in the Bush Presidency' (in Presidential Studies Quarterly, 2009) and 'Leadership by the Famous: Celebrity as Political Capital', in Dispersed Democratic Leadership, edited by J. Kane et al. (Oxford University Press, 2009).

Karen Tindall, Research School of Social Sciences, Australian National University, Coombs Building, Canberra ACT 0200, Australia; email: Karen.Tindall@anu.edu.au

\section{References}

Australian Associated Press (AAP) (2007) 'Garrett Denies Selling Out his Beliefs', The Age [online], 1 April. Available at: http://www.theage.com.au/news/National/Garrett-denies-selling-out-his-beliefs/2007/04/01/1175366059973.html.

Bang, H. (ed.) (2003) Governance as Social and Political Communication. Manchester: Manchester University Press.

Bang, H. (2004) 'Culture Governance: Governing Self-Reflexive Modernity’, Public Administration, 82 (1), 157-90.

Bang, H. (2005) 'Among Everyday Makers and Expert Citizens', in J. Newman (ed.), Remaking Governance: Peoples, Politics and the Public Sphere. Bristol: The Policy Press, pp. 159-79.

Bang, H. (2007) 'Parties in the Swing: Between Democratic Representation and Communicative Management'. Mimeo, Department of Political Science, University of Copenhagen.

Bang, H. (2008) 'Between Democracy and Good Governance', JPoX - Journal on Political Excellence [online]. Available at: http://jpox.eu/component/streams/view,content/cid,211'/' [Accessed 12 December 2009].

Bang, H. (2009) “"Yes We Can”: Identity Politics and Project Politics for the Late-Modern World', Urban Research and Practice, 2 (2), 1-21.

Bang, H. and Sørensen, E. (2001) 'The Everyday Maker: Building Social rather than Political Capital', in P. Dekker and E. Uslaner (eds), Social Capital and Participation in Everyday Life. London: Routledge, pp. 148-61.

Beck, U. (1992) Risk Society. London: Sage.

Beck, U., Giddens, A. and Lash, S. (1984) Reflexive Modernisation: Politics, Tradition and the Aesthetics of Modern Social Order. Oxford: Blackwell.

Bell, S. and Hindmoor, A. (2009) Rethinking Governance: The Centrality of the State in Modern Society. Port Melbourne: Cambridge University Press.

Blyth, M. and Katz, R. S. (2005) 'From Catch-All Politics to Cartelization', West European Politics, 28 (1), $33-60$.

Boorstin, D. J. (1961) The Image, or, What Happened to the American Dream. London: Weidenfeld and Nicholson.

Boykoff, M. and Goodman, M. (2009) 'Conspicuous Redemption? Reflections on the Promises and Perils of the "Celebritization" of Climate Change', Geoforum, 40 (3), 395-406.

Braudy, L. (1986) The Frenzy of Renown: Fame and its History. Oxford: Oxford University Press.

Brockington, D. (2009) Celebrity and the Environment: Fame, Wealth and Power in Conservation. London: Zed. 
Clarke, R. (ed.) (2009) Celebrity Colonialism: Fame, Power and Representation in Colonial and Postcolonial Cultures. Newcastle upon Tyne: Cambridge Scholars Publishing.

Cooper, A. F. (2008) Celebrity Diplomacy. Boulder CO: Paradigm Publishers.

Corner, J. and Pels, D. (2003) 'The Restyling of Politics', in J. Corner and D. Pels (eds), Media and the Restyling of Politics. London: Sage, pp. 1-15.

Cowen, T. (2000) What Price Fame. Cambridge MA: Harvard University Press.

Drake, P. and Higgins, M. (2006) " "I'm a Celebrity, Get me into Politics": The Political Celebrity and the Celebrity Politician', in S. Holmes and S. Redmond (eds), Framing Celebrity. London: Routledge, pp. 87-100.

Drezner, D. W. (2007) 'Foreign Policy Goes Glam', The National Interest, Nov/Dec, 22-8.

Duvall, S. (2007) 'A Star is Made: News Coverage of Celebrity Politics in the 2000 and 2004 US Presidential Elections'. Paper presented at the Political Science Association Conference, University of Bath, April.

Fain, S. (2008) 'Celebrities, Poverty and the Mediapolis: A Case Study of the One Campaign'. Paper delivered at the Media and Humanity Conference, September.

Gamson, J. (1994) Claims to Fame: Celebrity in Contemporary America. Berkeley CA: University of California Press.

Garthwaite, C. and Moore, T. (2008) 'The Role of Celebrity Endorsements in Politics: Oprah, Obama, and the 2008 Democratic Primary' [online]. Available at: http://www.econ.umd.edu/ garthwaite/celebrityendorsements_ garthwaitemoore.pdf [Accessed 7 June 2010].

Giddens, A. (1991) The Consequence of Modernity. Stanford CA: Stanford University Press.

Giles, D. (2000) Illusions of Immortality: A Psychology of Fame and Celebrity. New York: Macmillan.

Hajer, M. A. (2009) Authoritative Governance: Policy-Making in the Age of Mediatization. Oxford: Oxford University Press.

't Hart, P. and Tindall, K. (2009) 'Leadership by the Famous: Celebrity as Political Capital', in J. Kane, H. Patapan and P. 't Hart (eds), Dispersed Democratic Leadership: Origins, Dynamics, and Implications. Oxford: Oxford University Press, pp. $255-78$.

Hartley, J. (1996) Popular Reality: Journalism, Modernity, Popular Culture. London: Edward Arnold.

Hautamaki, J. and Kaarto, H. (2006) 'Politics Goes Entertainment', Helsingin Sanomat, 3 December [online]. Available from: http://www.hs.fi/english/article/Politics+goes+entertainment/1135223472392.

Held, D. (1995) Democracy and the Global Order: From the Modern State to Cosmopolitan Governance. Cambridge: Polity Press.

Holmes, S. and Redmond, S. (2006) Framing Celebrity: New Directions in Celebrity Culture. London: Routledge.

Hughes-Freeland, F. (2007) 'Charisma and Celebrity in Indonesian Politics', Anthropological Theory, 7 (2), 177-200.

Kaufman, G. (2006) 'Live 8, One Year Later: G8 Promises are Falling Short of Goals, Report Says'. Available online at: http://www.mtv.com/news/articles/1535470/20060629/u2.jhtml?headlines=true\&rsspartner=rsss YahooNewscrawler.

Keane, J. (2009) The Life and Death of Democracy. New York: Simon \& Schuster.

Klein, N. (2007) The Shock Doctrine: The Rise of Disaster Capitalism. Victoria: Allen Lane.

Lash, S. (1990) The Sociology of Postmodernism. London: Routledge.

Marsh, D. (2008) 'Understanding British Government: Analysing Competing Models', British Journal of Politics E International Relations, 10 (2), 251-68.

Marsh, D., Richards, D. and Smith, M. (2003) 'Unequal Plurality: Towards an Asymmetric Power Model of British Politics', Government and Opposition, 38 (3), 306-32.

Marshall, P. D. (1997) Celebrity and Power: Fame in Contemporary Culture. Minneapolis MN: University of Minnesota Press.

Meyer, D. S. and Gamson, J. (1995) 'The Challenge of Cultural Elites: Celebrities and Social Movements', Sociological Inquiry, 62 (2), 181-206.

Meyer, T. (2002) Media Democracy: How the Media Colonize Politics. Cambridge: Polity Press.

Monaco, J. (1978) Celebrity: The Media as Image Makers. New York: Doubleday.

Monbiot, G. (2005) 'Africa's New Best Friends', The Guardian, 5 July. Available at: http://www.guardian.co.uk/politics/ 2005/jul/05/internationalaidanddevelopment.development [Accessed 7 June 2010].

Mukherjee, J. (2004) 'Celebrity, Media and Politics: An Indian Perspective', Parliamentary Affairs, 57 (1), 80-92.

Nash, K. (2008) 'Global Citizenship as Show Business:The Cultural Politics of Make Poverty History', Media Culture Society, 30 (1), 167-81. 
Needham, C. (2005) 'Brand Leaders: Clinton, Blair and the Limitations of the Permanent Campaign', Political Studies, 53 (2), 343-61.

Perloff, M. R. (1998) Political Communication: Politics, Press and Public in America. Mahwah NJ: Erlbaum.

Pierre, J. and Peters, G. (2000) Governance, Politics and the State. Basingstoke: Palgrave.

Pringle, H. (2004) Celebrity Sells. London: Wiley.

Rojek, C. (2001) Celebrity. London: Reaktion Books.

Saward, M. (2006) 'The Representative Claim', Contemporary Political Theory, 5 (3), 297-318.

Sireau, N. and Davis, A. (2007) 'Interest Groups and Mediated Mobilisation: Communication in the Make Poverty History Campaign', in A. Davis (ed.), The Mediation of Power. Abingdon: Routledge, pp. 131-50.

Street, J. (2004) 'Celebrity Politicians: Popular Culture and Political Representation', British Journal of Politics E International Relations, 6 (4), 435-52.

Street, J. (2005) 'Politics Lost, Politics Transformed, Politics Colonised? Theories of the Impact of Mass Media', Political Studies Review, 3 (1), 17-33.

Thrall, T., Lollio-Fakhreddine, J., Berent, J., Donnelly, L., Herrin, W., Paquette, Z., Wenglinski, R. and Wyatt, A. (2008) 'Star Power: Celebrity Advocacy and the Evolution of the Public Sphere', The International Journal of Press/Politics, 13 (4), 362-84.

Turner, G. (2004) Understanding Celebrity. London: Sage.

Van Zoonen, L. (2006) 'The Personal, the Political and the Popular: A Women's Guide to Celebrity Politics', European Journal of Cultural Studies, 9 (3), 287-301.

Weiskel, T. (2005) 'From Sidekick to Sideshow: Celebrity, Entertainment, and the Politics of Distraction. Why Americans Are "Sleepwalking towards the End of the Earth" ', American Behavioral Scientists, 49 (3), 393-403.

West, D. and Orman, J. (2003) Celebrity Politics. Englewood Cliffs NJ: Prentice Hall. 